\title{
COSO's Conceptual Framework to Internal Control Management Risk in Higher Education Management
}

\author{
Ahmad Riyadi $^{1}$, Yennisa ${ }^{2}$, Laela Sagita ${ }^{3}$ \\ \{ahamdriyadi@upy.ac.id ${ }^{1}$,yennisa.icha@upy.ac.id², laelasagita@upy.ac.id $\left.\mathrm{d}^{3}\right\}$ \\ 1,2,3 Universitas PGRI Yogyakarta, Yogyakarta, Indonesia
}

\begin{abstract}
Ministry of Research, Technology and Higher Education of the Republic of Indonesia (Kemenristekdikti) establish five elements to conduct economic growth and country competitiveness in industry revolution 4.0 through the integration of university governance to academic behavior. Kemenristekdikti synergize the gap between the high tech digitalization era and higher education with external quality assurance system (SPME) and internal quality assurance system (SPMI) policy. UPY conducts internal evaluation using Internal - external matrix analysis (IE Matrix) to strengthen up the management and governance. The result is that UPY needs intensive and stable program implementation to achieve the whole key performance indicator. This study is qualitative research and conduct with a case study in UPY using COSO's Framework conduct risk management and internal control in UPY. This study adopts three stages to conduct case study research. The result can be used and as a reference to the other Higher Education (University) in the same quadrants with UPY (B Institution Accredited by BAN PT). This study suggests that COSO Framework implementation that integrated with Internal Quality This study suggests that COSO Framework implementation that integrated with Internal Quality Assurance can enhance Higher Education performance from internal control, risk assessment, and effective monitoring process.
\end{abstract}

Keywords: COSO Framework, Higher Education, UPY.

\section{Introduction}

Global industries/businesses are facing industrial revolution 4.0 which is affect our daily activities. Basis changing in this high tech digitalization era is in quality of information; more relevant and realtime [1]. This major changes affected people daily activities. Industry revolution 4.0 has a significant impact on business even in higher education. The role of higher education is to provide human resources with better psychomotor, cognitive and affective domain. Indonesia's government is in charge of monitoring higher education activities [2]. This high tech digitalization era brings higher education into the awareness of university governance issues. Different geographical and social culture barrier in Indonesia's higher education is the most concern for applying government policy. Another challenge is the trade-off between traditional people beliefs and modern society [3].

Ministry of Research, Technology and Higher Education of the Republic of Indonesia (Kemenristekdikti) establish five elements to conduct economic growth and country competitiveness in industrial revolution 4.0. One of the elements is higher education governance policy more adaptive and responsive to this high tech digitalization era. This 
challenge higher education to improve its governance which eligible with the global change. The impact on higher education is in transfer knowledge, the role itself, strategy, and university governance. The most difficult part is the integration of university governance to the academic behavior. Kemenristekdikti synergize the gap between the high tech digitalization era and higher education with external quality assurance system (SPME) and internal quality assurance system (SPMI) policy. The role of SPME and SPMI is to improve the quality of higher education in Indonesia. Higher education has to comply with the accreditation held by BAN-PT to qualified in National Standards on Higher Education (SNPT) [4]. Universitas PGRI Yogyakarta (UPY) has the obligation to improve the quality of human resources to fits in the industry revolution 4.0. UPY establish the SPMI policy with the sustainability of PPEPP cycle implementation. UPY establish the Quality Assurance Board to conduct monitoring both academics and non-academics for the first start. The next step is to establish 35 higher education standards. Internal evaluation summarizes the UPY achievement to conduct PPEPP cycle implementation with a rate of $71 \%$. This report concludes that UPY still not achieve 35 standards in the whole aspects.

BAN-PT decree UPY institutional accreditation with 'B' criteria in 2019. In another way, UPY also monitoring competitive aspects through mapping of higher education rank in Indonesia like webometrics, 4ICU, and Kemenristekdikti. UPY webometric's rank in DIY was on 23, 370 in national, and 15.335 worldwide on July 23 2018. Data 4ICU rank of UPY was sliding down before on 15 in DIY but increased in national to 160 and positioned 8878 worldwide on March 16 2018. Kemenristekdikti rank of UPY was sliding down to 212 in 2018 from 172 in 2017 and positioned in the third cluster by mapping of higher education performance. The component of mapping this performance are a) human resources quality; b) the board quality; c) quality of student affairs activity; d) research and science publication quality and e) innovation quality.

UPY conducts an internal evaluation to strengthen up the management and governance. Internal-external matrix analysis (IE Matrix) was showing the achievement in 2014-2018 in the aspect of vision, mission and governance, student affairs, human resources, curriculum \& learning, financial \& cooperation, and research \& community service putting UPY in the fourth quadrant. This quadrant means UPY performance running well through intensive strategy (market penetration and product development) and integrative strategy. UPY more specific focus on intensive and stability strategy. This means UPY needs intensive and stable program implementation to achieve the whole key performance indicator. The programs can develop strategy in market penetration and integrative community service. UPY needs a management strategy to deal with national competitive and positioning achievement in 2023 . UPY also needs to consider the innovation aspect performance key of Kemenristekdikti rank.

Higher education is an organization that can self evaluate and conduct risk management. The ability to identifying risk and adapting to external environment transition is one of the key success factors of the organization [2]. Managerial establish policy to respond to the risk after being identified. Managerial set an approach to conduct risk management and risk response. Many business entities conduct a holistic approach to identify risk with Enterprise Risk Management (ERM). ERM implementation enhances risk awareness in an entity then increase decision-making ability to optimize business performance [5]. COSO Framework conduct risk management and internal control both involving financial and non-financial aspect. Entity (both business and non-business) needs internal control to achieve the goals. Internal control elements by COSO Framework 2013 are 1) environment control, 2) risk assessment, 3) activity control, 4) information and communication, and 5) monitoring and evaluation. 
Research academic about COSO implementation in higher education is uncommon to conduct. This is because COSO's framework is, in fact, more suitable in a business entity. ERM implementation minimizes fraud risk in the production and sales department Food and Beverages company in Surabaya [6]. Research on energy enterprises' internal control conducted by Lingyu Wang [7]. COSO can be implemented in a non-business entity include higher education. COSO implementation improves the governance and quality assurance system in the university. Internal Control as the element of COSO implementation has a significant and positive impact on university governance through risk assessment [8].COSO implementation both internal control and risk assessment that entity could set a risk profile. A risk profile entity could lead to managerial policy as a risk assessment. Management is in charge to conduct risk management including to prevent the risks.

\section{Research Methode}

This study is qualitative research and conduct with a case study in UPY. Qualitative research method with case study conduct with deepening with an exploration of the related system (the case itself) and collecting a variety of information [9].

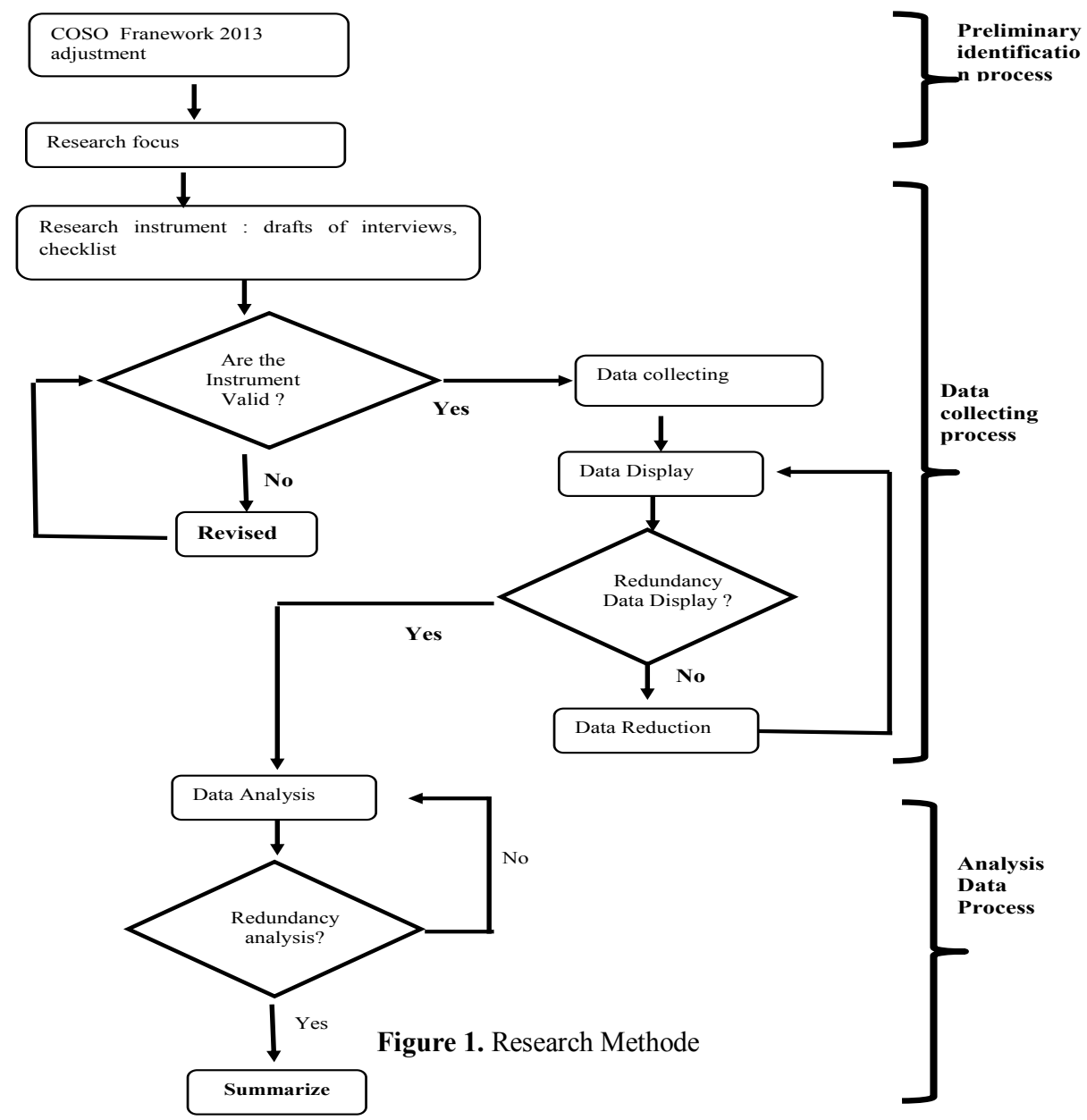


This study adopts three stages to conduct case study research [10];1) preliminary identification process, 2) collecting data process, 3) data analysis process. The preliminary identification process consists of determining and adjusting to COSO's Framework 2013 with UPY (the management) further it leads to research focus. The next stage is collecting data within sourcing of activity in UPY, governance documentation, and top management of UPY. Various task conduct in collecting data process stage are instrument preparation, data collection, and data reduction. This study use checklist based on five component of COSO with 17 principles, drafts structured-interview to collect data from the top management of UPY. the final stage is analyzing data to summarize and recommend case study focus that been identified in the preliminary stage.

\section{Result and Discussion}

\subsection{Research Result}

Control mechanism to achieve vision, mission, and strategy of UPY is conducted periodically and systematically. Management conducts management evaluation meetings at the end of the semester. The output of the meetings is self-evaluation and feedback from the monitoring and evaluation process. This process captured by COSO framework standards [5] through implementation to the internal control in UPY.

Table1. Implementation COSO Framework to the internal control in UPY

\begin{tabular}{|c|c|}
\hline COSO Principles & Activity Identification \\
\hline \multicolumn{2}{|l|}{ Environment Control } \\
\hline \multirow[t]{5}{*}{$\begin{array}{l}\text { P1. Commitment to conduct integrity and } \\
\text { ethical values }\end{array}$} & $\begin{array}{l}1.1 \text { Identification of ethics code } \\
\text { documentation (both lecturer and student } \\
\text { college. }\end{array}$ \\
\hline & 1.2 Management evaluation activity. \\
\hline & $\begin{array}{l}\text { 1.3 Credo as a measurement to commitment } \\
\text { and integrity }\end{array}$ \\
\hline & $\begin{array}{l}1.4 \text { University values as a measurement to } \\
\text { commitment and integrity }\end{array}$ \\
\hline & $\begin{array}{l}1.5 \text { Definition of Unggul from UPY } \\
\text { perspective to achieve the goals. }\end{array}$ \\
\hline \multirow{2}{*}{$\begin{array}{l}\text { P2. UPY independent conduct activity as an } \\
\text { operational function to develop and } \\
\text { implement the internal control }\end{array}$} & $\begin{array}{l}\text { Independent board in charged to internal } \\
\text { control (independent commissioner) }\end{array}$ \\
\hline & Quality and quantity of internal auditor \\
\hline \multirow{2}{*}{$\begin{array}{l}\text { P3. UPY establishes internal auditor, } \\
\text { organization line of structures, and } \\
\text { responsibility to achieve the goals. }\end{array}$} & $\begin{array}{ll}1.1 & \text { Requirement documentation of Statuta, } \\
\text { SOTK, and Anjab. }\end{array}$ \\
\hline & $\begin{array}{lll}1.1 & \begin{array}{l}\text { Requirement } \\
\text { organization structure }\end{array} & \text { of } \\
\end{array}$ \\
\hline \multirow{3}{*}{$\begin{array}{l}\text { P4. UPY commit to conduct recruitment, } \\
\text { develop and retain competent individuals to } \\
\text { achieve the goals }\end{array}$} & $\begin{array}{l}\text { 4.1 Human resources documentation about } \\
\text { recruitment, development, and retention. }\end{array}$ \\
\hline & $\begin{array}{l}\text { 4.2 Documentation management related to } \\
\text { human resources }\end{array}$ \\
\hline & $\begin{array}{l}4.3 \text { Individuals development of competency } \\
\text { mechanism }\end{array}$ \\
\hline P5. UPY conduct accountability in internal & 5.1 Implement accountable line of structure by \\
\hline
\end{tabular}




\begin{tabular}{|c|c|}
\hline COSO Principles & Activity Identification \\
\hline control to achieve the goals. & $\begin{array}{l}\text { internal/external audit and reporting } \\
\text { documentation. }\end{array}$ \\
\hline \multicolumn{2}{|l|}{ Risk Assessment } \\
\hline \multirow[t]{2}{*}{$\begin{array}{l}\text { P6. UPY has detail missions that specified } \\
\text { about risk assessment identification }\end{array}$} & $\begin{array}{ll}6.1 & \begin{array}{l}\text { RIP documentation as a long term } \\
\text { planning }\end{array} \\
\end{array}$ \\
\hline & $\begin{array}{l}6.2 \text { Annual planning program that clearly } \\
\text { specified on RENSTRA }\end{array}$ \\
\hline $\begin{array}{l}\text { P7. UPY conduct risk management to } \\
\text { identify and analyze the risks }\end{array}$ & 7.1 Periodically self-evaluation activity \\
\hline $\begin{array}{l}\text { P8. UPY considers risk potential that could } \\
\text { obstruct the achievement of the goals. }\end{array}$ & Periodically external audit activity \\
\hline $\begin{array}{l}\text { P9. UPY identify and value for significant } \\
\text { changes that could impact to internal control } \\
\text { system }\end{array}$ & $\begin{array}{l}\text { UPY conduct internal mechanism to respond to } \\
\text { the external and internal changes. }\end{array}$ \\
\hline \multicolumn{2}{|l|}{ Control Activity } \\
\hline \multirow{3}{*}{$\begin{array}{l}\text { P10. UPY set and develop control activity to } \\
\text { preventing risks to an acceptable level }\end{array}$} & 10.1 Control activity to university governance \\
\hline & 10.1 Control activity to human resources \\
\hline & 10.2 Control activity to financial \\
\hline $\begin{array}{l}\text { P11. UPY set and develop general control } \\
\text { activity over technology to achieve the goals }\end{array}$ & Integrated system dan database \\
\hline $\begin{array}{l}\text { P12. UPY implement control activity by } \\
\text { management policy. }\end{array}$ & Internal control by SPMI \\
\hline \multicolumn{2}{|l|}{ Information and communication } \\
\hline $\begin{array}{l}\text { P13. UPY using relevant information to } \\
\text { enhance the component of internal control }\end{array}$ & Management of documentation and activities \\
\hline $\begin{array}{l}\text { P14. UPY communicate information } \\
\text { internally include setting goal and } \\
\text { responsibility to support internal control. }\end{array}$ & There is no feedback internally. \\
\hline \multirow{4}{*}{$\begin{array}{l}\text { P15. UPY communicate with external related } \\
\text { to the problem of internal control function }\end{array}$} & 15.1 Updating data to the external party \\
\hline & 15.2 External party direction \\
\hline & 15.3 External audit (financial) \\
\hline & 15.4 Availability of internal auditor \\
\hline \multicolumn{2}{|l|}{ Controlling } \\
\hline $\begin{array}{l}\text { P16. UPY choose, develop, and implement } \\
\text { routine evaluation to ensure that internal } \\
\text { control component has been implemented. }\end{array}$ & Evaluation tp internal control activities (SPMI) \\
\hline $\begin{array}{l}\text { P17. UPY evaluate and communicate internal } \\
\text { control deficiency to the board of directors } \\
\text { and managerial. }\end{array}$ & Evaluation feedback \\
\hline
\end{tabular}

Based on the identification of the application of the COSO's framework at UPY in table 1. Several conclusions representation below. 
Table 2. High-Risk Governance Identification

\begin{tabular}{|c|c|c|}
\hline \multicolumn{2}{|c|}{$\begin{array}{l}\text { COSO Component } \\
\text { and Principles }\end{array}$} & Governance \\
\hline \multirow[t]{5}{*}{ Environment control } & $\mathrm{P} 1$ & UPY has ethics code but there is no Ethics Board function \\
\hline & $\mathrm{P} 2$ & Unstandardized auditor internal qualification \\
\hline & $\mathrm{P} 3$ & The different concept in UPY manajement \\
\hline & $\mathrm{P} 4$ & Unsynchronized human resources data \\
\hline & P5 & Inconsistency managerial accountability \\
\hline \multirow[t]{4}{*}{ Risk Assessment } & P6 & Nonoptimal creation for Developing Core Planning \\
\hline & & $\begin{array}{l}\text { Annual program not based on long term planning (Renstra) and } \\
\text { priority scale }\end{array}$ \\
\hline & P7 & Self-evaluation conduct incidentally \\
\hline & P8 & Rarely on using fraud risk \\
\hline \multirow[t]{4}{*}{ Activity Control } & P10 & $\begin{array}{l}\text { Management Evaluation Meetings has no comprehensive analysis } \\
\text { and lack of sources data }\end{array}$ \\
\hline & & $\begin{array}{l}\text { Inconsistency and nonoptimal human resources control by SKP, } \\
\text { DP3 and BKD }\end{array}$ \\
\hline & & Manual financial control \\
\hline & P12 & $\begin{array}{l}\text { Good organization culture but not all individuals have the same } \\
\text { understanding of the university culture }\end{array}$ \\
\hline \multirow[t]{4}{*}{$\begin{array}{l}\text { Information } \\
\text { Communication }\end{array}$} & P13 & $\begin{array}{l}\text { Management data still not create relevant information for decision } \\
\text { making }\end{array}$ \\
\hline & P14 & There is no feedback for internal communication \\
\hline & P15 & There is no External audit (financial) \\
\hline & & UPY has no independent audit committee \\
\hline \multicolumn{3}{|r|}{ Unevaluated internal Qually Assurance system } \\
\hline & Tabel & Medium Risk Governance Identification \\
\hline \multicolumn{2}{|c|}{$\begin{array}{c}\text { COSO Component and } \\
\text { Principles } \\
\end{array}$} & Governance \\
\hline \multirow[t]{6}{*}{ Environment Control } & P 1 & $\begin{array}{l}\text { Nonoptimal feedback for recommendation from Management } \\
\text { Evaluation Meetings }\end{array}$ \\
\hline & & There is no measurement for service value motto (S3C3) \\
\hline & & $\begin{array}{l}\text { There is no measurement for implementation university values } \\
\text { "APIK \& Unggul }\end{array}$ \\
\hline & $\mathrm{P} 2$ & UPY still develop independent Internal Control Departement \\
\hline & P 3 & Unevaluated Statuta, SOTK, Anjab \\
\hline & $\mathrm{P} 4$ & $\begin{array}{l}\text { Un-updated recruitment, development and retention for human } \\
\text { resources standards }\end{array}$ \\
\hline Risk Assessment & - & \\
\hline Activity Control & P 11 & Unintegrated database \\
\hline \multirow{2}{*}{$\begin{array}{l}\text { Information } \\
\text { Communication }\end{array}$} & P 15 & Unstructured data collection \\
\hline & & Lack of control for feedback of LLDikti recommendation \\
\hline $\begin{array}{l}\text { Monitoring } \\
\text { Evaluation }\end{array}$ & P 17 & Nonoptimal for evaluation feedback \\
\hline
\end{tabular}


Based on table 4 and table 5 this study elaborates on the alternative approach as a solution to reduce university governance risks. This study conducts a grand tour to the redundancy level to find the best alternative solution by selection and reduction process. Table 4 are alternative solutions that offered by this study

Tabel 4. Correction to High Risk Governance Identification

\begin{tabular}{|c|c|c|}
\hline \multicolumn{2}{|c|}{$\begin{array}{l}\text { COSO Component and } \\
\text { Principles }\end{array}$} & Governance \\
\hline \multirow[t]{6}{*}{ Environment Control } & \multirow[t]{2}{*}{$\mathrm{P} 1$} & $\begin{array}{l}\text { Socialize ethics code and establish an ethics code board for } \\
\text { both staf and college student }\end{array}$ \\
\hline & & Formulate ethics code \\
\hline & $\mathrm{P} 2$ & Conduct training and certified internal auditor \\
\hline & P3 & Sosialization a concept manajerial UPY \\
\hline & $\mathrm{P} 4$ & Design integrated database system \\
\hline & P5 & $\begin{array}{l}\text { Conduct reporting extensively and disseminate to the entire } \\
\text { level of management }\end{array}$ \\
\hline \multirow[t]{4}{*}{ Risk Assessment } & \multirow[t]{2}{*}{ P6 } & $\begin{array}{l}\text { Conduct evaluation to the Development Core Planning and } \\
\text { establish an evaluation mechanism }\end{array}$ \\
\hline & & Socialize Renstra's implementation in Annual Program \\
\hline & $\mathrm{P} 7$ & Updating data extensively for annual evaluation process \\
\hline & P8 & $\begin{array}{l}\text { Conduct training for internal auditor or hire an external } \\
\text { auditor }\end{array}$ \\
\hline \multirow[t]{4}{*}{ Activity control } & \multirow[t]{3}{*}{$\mathrm{P} 10$} & $\begin{array}{l}\text { Update data extensively in the entire management unit, } \\
\text { improve analysis dan commit to implementing feedback } \\
\text { recommendations. }\end{array}$ \\
\hline & & $\begin{array}{l}\text { Conduct analysis for the result of SKP, DP3, and BKD to } \\
\text { determine human resources development policy }\end{array}$ \\
\hline & & $\begin{array}{l}\text { Conduct external audit (financial) periodically and improve } \\
\text { management capacity and financial resources }\end{array}$ \\
\hline & P12 & $\begin{array}{l}\text { Implement sustainable internal quality assurance and conduct } \\
\text { evaluation process }\end{array}$ \\
\hline \multirow{4}{*}{$\begin{array}{l}\text { Information } \\
\text { Communication }\end{array}$} & P13 & Updating data extensively and improve analysis of capacity \\
\hline & P14 & $\begin{array}{l}\text { Enhance information and communication function to improve } \\
\text { the decision-making process and minimize misleading } \\
\text { information }\end{array}$ \\
\hline & \multirow[t]{2}{*}{ P15 } & $\begin{array}{l}\text { Socialize external audit (financial) function and build } \\
\text { commitment to enhance financial management accountability }\end{array}$ \\
\hline & & Establish Monitoring Board \\
\hline $\begin{array}{l}\text { Monitoring } \\
\text { Evaluation }\end{array}$ & P16 & Conduct Internal Quality Assurance periodically \\
\hline
\end{tabular}

\subsection{Discussions}

COSO Framework can be implemented in University Governance with some adjustments between COSO Principles and University Governance. Five component COSO and the principles implemented in university governance to create description partially and then analyze to improve the internal control process function. Internal control higher education can be evaluated by SWOT analysis. For the term of internal control, SWOT analysis and COSO Framework have a different meaning. SWOT analysis emphasize for strength, weaknesses, 
opportunity, and threat aspect which differentiates the internal and external domain. COSO Framework has not differentiated internal and external domain explicitly but focus on five aspects point; environment control, risk assessment, activity control, information and communication, monitoring, and evaluation. SWOT analysis can be used to enhance COSO Framework implementation in the term decision of an alternative solution. COSO Framework has different methods from the quality assurance system method. Internal control for higher education implemented by Internal Quality Assurance emphasizes in comparison from the result expected from management and the standards. Management focuses on the quantitative method but COSO Framework emphasizes on the managerial process. COSO with a qualitative method implemented in internal control higher education which Internal Quality Assurance in charge-in.

COSO Framework elements describe explicitly on the second standard in institution accreditation instrument by BAN PT substantially and in managerial internal control process. Instrument Standard number 2 in BAN PT consists of governance control, leadership, managerial, and quality assurance. Integration control between COSO Framework (internal) and BAN PT institution accreditation (external) improve the internal control of higher education. Novelty from this study is integrated implementation between COSO Framework, Internal Quality Assurance of Higher Education, and instrument of BAN PT Accreditation. This study claims that it can improve internal control in the management process, output and outcome. This study is different from Wang [7] that conducts COSO Framework integration with the financial management system. This is in accordance with one of COSO's Framework goal is enhancing financial quality reporting.

COSO theory and financial quality reporting can be used to optimize the energy production system from energy enterprises. One specific matter left is sustainability improvement from this integration. This qualitative study is extremely subjective including research instruments and data. The result can be used and as a reference to the other Higher Education (University) in the same cluster with UPY (B Institution Accredited by BAN PT). This study suggests that COSO Framework implementation that integrated with Internal Quality Assurance can enhance Higher Education performance from internal control, risk assessment, and effective monitoring process.

\section{References}

[1] Gilchrist, Alasdair, Industry 4.0: The Industrial Internet of Things, Bangken, Nonthaburi, Thailand, 2016

[2] Harsya, Harun. Kesiapan Pendidikan Tinggi dalam Menghadapi Revolusi Industri 4.0 dalam Perspektif Kelembagaan. Prosiding Seminar Nasional ISSN 2443-1109 Vol 04, Nomor 1, p 187194.

[3] Schwab, Klaus, The Fourth Industrial Revolution. Crown Business Press, 2017

[4] BAN PT, 2017 : BAN PT. (2017). Peraturan BAN PT No 2 tahun 2017 tentang SAN-DIKTI. Jakarta: BAN-PT.

[5] Bohnert, A., Gatzert, N., Hoyt, R. E., \& Lechner, P. (2017). The relationship between enterprise risk management, value and firm characteristics based on the literature. Zeitschrift für die gesamte Versicherungswissenschaft, 106(3-4), 311-324.

[6] Amanda, Wijaya. Implementasi Fraud Risk Management untuk Meminimalkan Resiko Kecurangan (Fraud) pada bagian Produksi dan Penjualan Perusahaan Makanan Wanda Putra Kencana Surabaya. Jurnal Ilmiah Mahasiswa universiats Surabaya Vol.3 No.2, 2014, p 1-17. 
[7] Lingyu, Wang. Research on Internal Control Construction System of Energybased Enterprises Based on COSO and Financial Quality. IOP Conf. Series: Earth and Environmental Science 252 (2019) 032062, p 1-6.

[8] Yudianti, F. N., \& Suryandari, I. H. (2015). Internal control and risk management in ensuring good university governance. Journal of Education and Vocational Research, 6(2), p 6-12.

[9] John W. Creswell. (1998). Qualitative Inquiry And Research Design: Choosing Among Five Traditions. London: SAGE Publications

[10] Hardy, C., Harley, B., \& Phillips, N. (2004). Discourse analysis and content analysis: Two solitudes. Qualitative methods, 2(1), p 19-2. 